\title{
Voltammetric Trace Analysis of Uranium and Other Metals in Meta Rhyolite Rock Samples
}

\author{
Praveen K. TAmrakar and Krishna S. Pitre \\ Department of Chemistry, Dr. Hari Singh Gour University, Sagar-470 003, (M. P.) India
}

\begin{abstract}
Direct current polarography (DCP), differential pulse polarography (DPP) and differential pulse anodic stripping voltammetry (DPASV) have been successfully used for the simultaneous determination of trace metals in meta rhyolite rock samples. The polarograms/voltammograms of sample solutions were recorded in $0.1 \mathrm{M} \mathrm{KCl}, 0.1 \mathrm{M}$ ammonium tartrate and 0.1 M KSCN supporting electrolyte separately. The results indicated the presence of $\mathrm{Zn}^{2+}, \mathrm{Fe}^{3+}, \mathrm{Mn}^{2+}, \mathrm{Cu}^{2+}$ and $\mathrm{UO}_{2}{ }^{2+}$ metal ions. Uranium gave a well-defined polarographic wave/peak with $E_{1 / 2} / E_{\mathrm{P}}-0.26 /-0.26 \mathrm{~V} v s$. SCE in 0.1 M KSCN. The method of standard addition was for the quantitative analysis of trace metals, which revealed the following results: $\mathrm{Zn}^{2+}$ (22.22), $\mathrm{Fe}^{3+}(147.10), \mathrm{Mn}^{2+}(5.50), \mathrm{Cu}^{2+}(28.58)$ and $\mathrm{UO}_{2}^{2+}(0.059) \mathrm{mg} \mathrm{g}^{-1}$ of the sample. The observed voltammetric results were compared with those obtained using AAS. Statistical treatment of the observed voltammetric data revealed high accuracy and good precision of the determination.
\end{abstract}

(Received January 24, 2000; Accepted May 24, 2000)

\section{Introduction}

Uranium metal is inhomogeneously distributed in nature. The recovery of uranium from the earth's crust has been gaining much attention in recent years because of its ever-increasing demand in nuclear technology. It has been determined in different materials viz. ores, rocks, minerals and seawater etc. by several research workers. ${ }^{1-4}$ It occurs in rock materials at minor and trace levels. In meta rhyolite rock, uranium is present at a trace level, and is generally associated with Th, Cs, $\mathrm{Fe}, \mathrm{Mn}, \mathrm{Cu}, \mathrm{Si}$, and $\mathrm{Ca}^{5-8} \mathrm{An}$ analysis of uranium in natural origin (geological) samples is necessary not only in view of its significance for nuclear technology and economic value, but also for its environmental significance. Due to the importance of uranium and other metals, it is desirable to use an analytical technique that is highly sensitive especially at trace levels, specific, precise and yields much elemental information, even for a small sample.

Various analytical procedures based on the use of different instrumental techniques have been developed in the past for the determination of uranium and other trace metals in geological samples. ${ }^{9} 10$ Atomic absorption spectrometry (AAS) is being increasingly used for the determination of trace amount of metals in ores, minerals and rocks. ${ }^{11,12}$ Besides, X-ray fluorescence (XRF) analysis, neutron activation analysis (NAA), inductively coupled plasma atomic emission spectroscopy (ICP-AES) and sepctrophotometry have also been applied for such analyses. ${ }^{13-16}$ In the field of the trace analysis of metals, electroanalytical techniques have established themselves as versatile analytical tools for their quick and precise determination. With the development of several advanced electroanalytical techniques, such as differential pulse polarography (DPP), differential pulse anodic stripping voltammetry (DPASV) and adsorptive stripping voltammetry etc., problems related to the simultaneous multielemental determination of metals in different origin samples including geological samples have been simplified. ${ }^{17,18}$ The sensitivity of anodic stripping voltammetry has been greatly improved by using a thin mercury film on a glassy carbon fiber electrode ${ }^{19}$ and a gold film electrode. ${ }^{20}$ Currently, voltammetry and related techniques have emerged as powerful tools for the rapid and simultaneous qualitative and quantitative determination of trace metals in a variety of samples of biological, environmental, metallurgical, industrial and geological origin. ${ }^{21-25}$

The present paper deals with the application of DCP, DPP and DPASV for the trace analysis of metals in meta rhyolite rock samples. Special attention was paid to the uranium content of the sample. The voltammetric results were compared with those obtained using AAS and XRF methods.

\section{Experimental}

\section{Sample}

The meta rhyolite rock sample was collected from Ghatwari village near Kherli Bazar area, located $21 \mathrm{~km}$ north east of Multai Tehsil, Betul District, (M. P.) India.

\section{Apparatus}

Polarographic and voltammetric measurements were made on an Elico (India) pulse polarograph Model CL-90 coupled with a recorder X-Y polarocard (Model L. R. 108). The electrode system consisted of a dropping mercury electrode (DME) as a working electrode, a coiled platinum wire electrode as an auxiliary electrode and a saturated calomel electrode (SCE) as a reference electrode. The electrochemical cell, had a provision for inserting a bubbler for deaerating the solution by passing nitrogen gas. A glassy carbon fiber electrode (NF 12, Sigti Eletitiogitit, UK) was used for DPASV.

The $\mathrm{pH}$ measurements were made with a Systronics digital $\mathrm{pH}$ meter (Model 335). 
Table 1 Instrumental parameters

\begin{tabular}{lc}
\hline \multicolumn{1}{c}{ Parameter } & Value \\
\hline Initial applied voltage & $0.0 \mathrm{~V}$ vs. SCE \\
Sensitivity & $1 \mu \mathrm{A} / \mathrm{V}$ \\
C C compensation & 5 \\
I R compensation & 4 \\
Height of Hg & $140.0 \mathrm{~cm}$ \\
Time constant & $10 \mathrm{~ms}$ \\
Pulse amplitude & $50 \mathrm{mV}$ \\
Drop time & $0.5 \mathrm{~s}$ \\
Aquisition & fast \\
Scan rate & $12 \mathrm{mV} \mathrm{s}$ \\
O/P zero & 0 \\
Temperature & $25 \pm 20^{\circ} \mathrm{C}$ \\
On polarocard & $100 \mathrm{mV} \mathrm{cm}^{-1} / 200 \mathrm{mV} \mathrm{cm}^{-1}$ \\
$X$-Axis & $0.2 \mu \mathrm{A} \mathrm{cm} / 1 / 0.5 \mu \mathrm{A} \mathrm{cm}$ \\
$Y$-Axis & \\
\hline
\end{tabular}
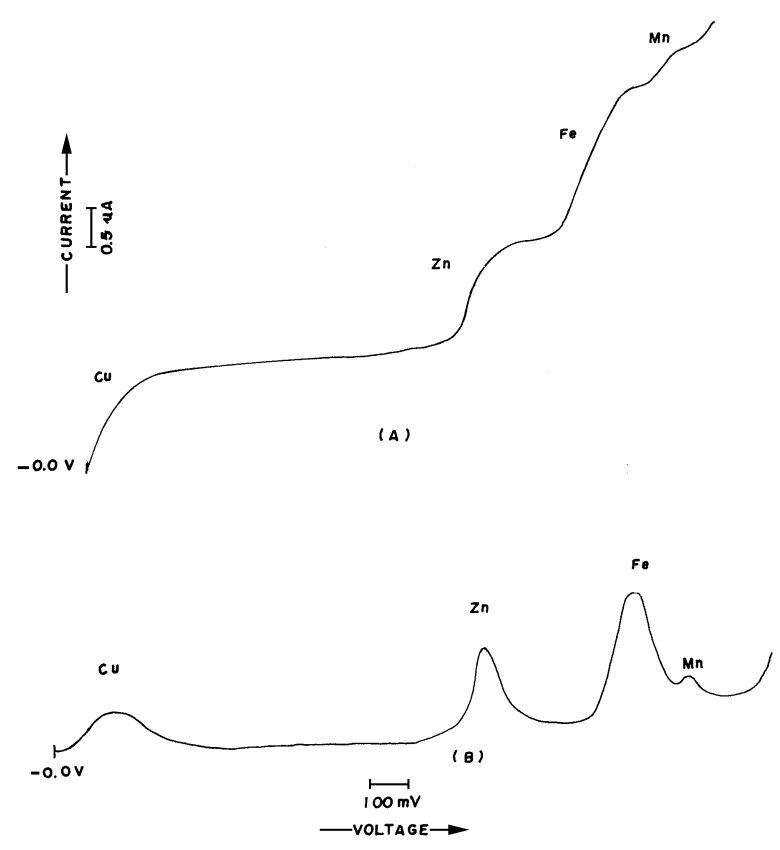

Fig. 1 (A) Direct current polarogram; (B) differential pulse polarogram of meta rhyolite rock sample in $0.1 \mathrm{M} \mathrm{KCl}+0.001 \%$ gelatin, $\mathrm{pH} 4.5 \pm 0.1$.

\section{Chemicals}

All of the chemicals used were of analytical reagent grade (BDH). Stock solutions of potassium chloride (1 M), ammonium tartrate $(1 \mathrm{M})$, potassium thiocyanate $(1 \mathrm{M}), \mathrm{Zn}^{2+}$, $\mathrm{Fe}^{3+}, \mathrm{Mn}^{2+}, \mathrm{Cu}^{2+}$ and $\mathrm{UO}_{2}^{2+}(0.01 \mathrm{M})$ were prepared by dissolving the required amoumt of their soluble salts in doubly distilled water. Gelatin $(0.1 \%)$ solution was prepared with hot distilled water. The solutions were standardized by known methods and diluted as required.

\section{Preparation of sample solution}

The meta rhyolite rock samples solution were prepared by an acid decomposition method. Finely pulverised rock sample (1 g) was heated with acid mixture of $20 \mathrm{ml}$ of $26.5 \mathrm{M} \mathrm{HF}$ and 15 $\mathrm{ml}$ of $11.6 \mathrm{~N}$ perchloric acid. The undissolved residue was dissolved by adding $5 \mathrm{ml}$ aqua-regia to the solution. The final volume was made up to $100 \mathrm{ml}$ with doubly distilled water and

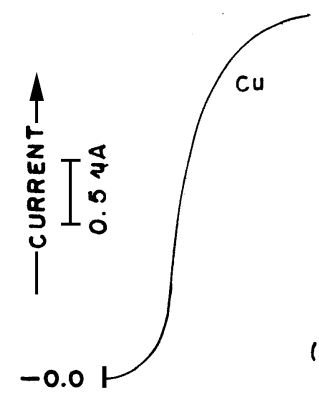

(A)
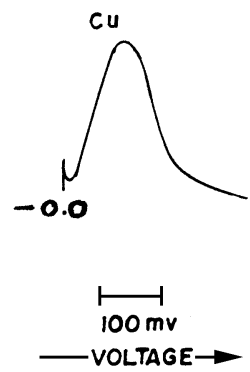

(B)

Fig. 2 (A) Direct current polarogram; (B) differential pulse polarogram of meta rhyolite rock sample in $0.1 \mathrm{M}$ ammonium tartrate $+0.001 \%$ gelatin, $\mathrm{pH} 5.0 \pm 0.1$ (only for $\mathrm{Cu}$ ).

subjected to polarographic/voltammetric analysis.

Preparation of analyte and recording of polarograms/ voltammograms

Experimental sets containing $10 \mathrm{ml}$ of the sample solution + $10 \mathrm{ml}$ of $\mathrm{KCl} / \mathrm{ammonium}$ tartrate/KSCN $(1 \mathrm{M})$ as supporting electrolyte $+1 \mathrm{ml}$ of gelatin $(0.1 \%)$ solution as a maximum suppressor, were prepared. The final volume of each test solution was made up to $100 \mathrm{ml}$ with doubly distilled water. The $\mathrm{pH}$ of the test solution was adjusted to $4.5 \pm 0.1$ and $5.0 \pm$ 0.1 respectively, using a dilute $\mathrm{KOH} / \mathrm{NH}_{4} \mathrm{OH}$ solution.

The analyte was placed in a polarographic cell equipped with the electrode assembly specified above. Pure nitrogen gas was passed through the test solution for $15 \mathrm{~min}$ at the beginning of the experiment. The polarograms and voltammograms were then recorded with the instrumental parameters indicated in Table 1. For DPASV, the deposition potential was fixed at -2.0 $\mathrm{V}$ in the case of $0.1 \mathrm{M} \mathrm{KCl}$ and at $-1.0 \mathrm{~V}$ in the case of $0.1 \mathrm{M}$ KSCN and $0.1 \mathrm{M}$ ammonium tartrate as a supporting electrolyte. The deposition time was $60 \mathrm{~s}$ and the resting period was $10 \mathrm{~s}$.

\section{Results and Discussion}

The d.c. polarogram and differential pulse polargram of the sample solution in $0.1 \mathrm{M} \mathrm{KCl}$ as a supporting electrolyte $(\mathrm{pH}=$ $4.5 \pm 0.1)$ produced three well-defined polarographic waves/peaks (Fig. 1) with $E_{1 / 2} / E_{\mathrm{p}}$ values $=-0.99 \mathrm{~V} /-1.11 \mathrm{~V}$, $-1.30 \mathrm{~V} /-1.50 \mathrm{~V}$ and $-1.51 \mathrm{~V} /-1.66 \mathrm{~V} v s$. SCE, indicating the presence of $\mathrm{Zn}^{2+}, \mathrm{Fe}^{3+}$ and $\mathrm{Mn}^{2+}$ respectively, in the sample.

Although under the said experimental conditions $\mathrm{Cu}^{2+}$ also gave a signal for its presence in the sample, it was not welldefined. For the determination of $\mathrm{Cu}^{2+}$, ammonium tartrate was used as supporting electrolyte. The d.c. polarogram and differential pulse polarogram (Fig. 2) of the sample solution in $0.1 \mathrm{M}$ ammonium tartrate $(\mathrm{pH}=5.0 \pm 0.1)$ produced a welldefined wave/peak with $E_{1 / 2} / E_{\mathrm{P}}$ value $=-0.14 \mathrm{~V} /-0.11 \mathrm{~V}$ vs. 


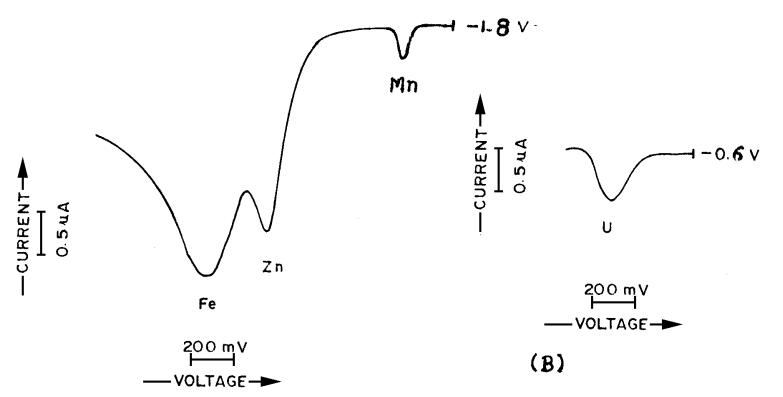

(A)

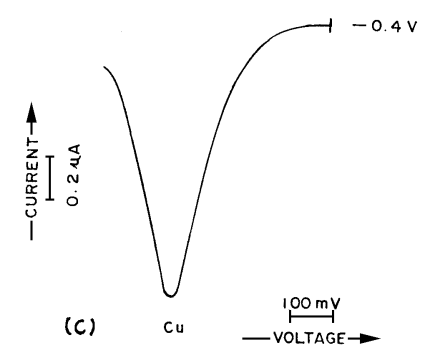

Fig. 3 Differential pulse anodic stripping voltammogram of meta rhyolite rock sample in: (A) $0.1 \mathrm{M} \mathrm{KCl}+0.001 \%$ gelatin, $\mathrm{pH} 4.5 \pm$ 0.1 ; (B) $0.1 \mathrm{M} \mathrm{KSCN}+0.001 \%$ gelatin, $\mathrm{pH} 2.5 \pm 0.1$ (only for $\mathrm{U}$ ); (C) $0.1 \mathrm{M}$ ammonium tartrate $+0.001 \%$ gelatin, $\mathrm{pH} 5.0 \pm 0.1$ (only for $\mathrm{Cu}$ ).

SCE indicating the presence of $\mathrm{Cu}^{2+}$ in the sample.

The differential pulse anodic stripping voltammograms (Figs. $3 \mathrm{~A}$ and $\mathrm{C}$ ) were recorded for the sample solution under identical experimental conditions using a glassy carbon fiber electrode. The figure shows the presence of $\mathrm{Zn}^{2+}, \mathrm{Fe}^{3+}$ and $\mathrm{Mn}^{2+}$ with $E_{\mathrm{P}}=$ $-0.96 \mathrm{~V},-0.70 \mathrm{~V}$ and $-1.56 \mathrm{~V}$ vs. SCE in $0.1 \mathrm{M} \mathrm{KCl}$ and $\mathrm{Cu}^{2+}$ with $E_{\mathrm{P}}=-0.05 \mathrm{~V} v s$. SCE in $0.1 \mathrm{M}$ ammonium tartrate.

\section{Analysis of uranium}

To investigate the presence of other metal ions in the sample, the polarogram and voltammogram were recoreded in $0.1 \mathrm{M}$ KSCN at $\mathrm{pH}=2.5 \pm 0.1$. The d.c. polarogram and the differential pulse polarogram (Fig. 4) of the sample solution produced a well-defined wave and peak, respectively, with $E_{1 / 2}=-0.26 \mathrm{~V}$ and $E_{\mathrm{P}}=-0.26 \mathrm{~V} v s$. SCE, indicating the presence of $\mathrm{UO}_{2}{ }^{2+}$ in the sample. The differential pulse anodic stripping voltammogram (Fig. 3B) also shows the presence of $\mathrm{UO}_{2}{ }^{2+}$ with $E_{\mathrm{P}}-0.24 \mathrm{~V} v s$. SCE in KSCN.

To confirm the presence of the said metal ions in the sample, a known quantity of standard solution of each metal ion was added to the analyte and the polarograms and voltammograms were recorded under identical experimental conditions. An increase in the wave and peak height of each metal ion signal was observed without any change in $E_{1 / 2}$ and $E_{\mathrm{P}}$.

Based on the presence of the said metal ions in the sample, synthetic samples with varying concentrations of the metal ions were prepared and their polarograms and voltammograms were recorded under identical experimental conditions as above. The results (Fig. 5) indicated no change in $E_{1 / 2}$ and $E_{\mathrm{P}}$ of the abovementioned metal ions, thus confirming the possibility of an accurate oligo qualitative and quantitative (Table 2) determination of the said metal ions in the sample without interference due to the metal ions on the determination of each other in the sample.
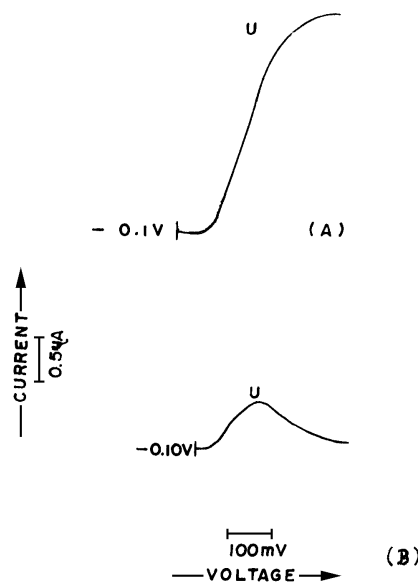

Fig. 4 (A) Direct current polarogram; (B) differential pulse polarogram of meta rhyolite rock sample in $0.1 \mathrm{M} \mathrm{KSCN}+0.001 \%$ gelatin. $\mathrm{pH} 2.5 \pm 0.1$ (only for $\mathrm{U}$ ).

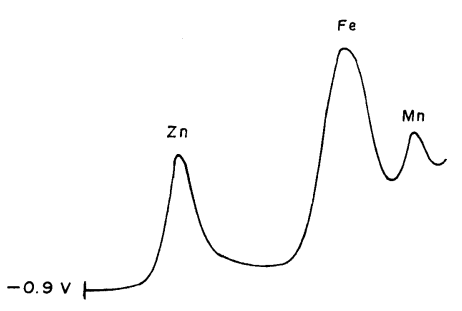

(A)
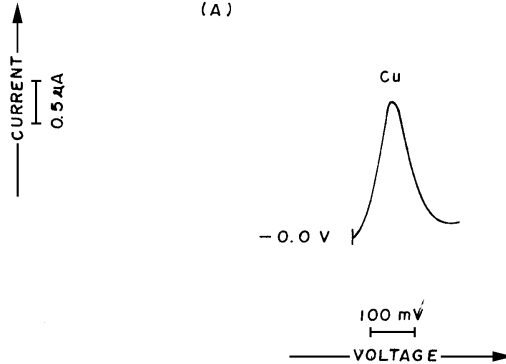

(c)

Fig. 5 Differential pulse polarogram of a synthetic sample containing $\mathrm{Zn}^{2+}(0.65), \mathrm{Fe}^{3+}(6.69), \mathrm{Mn}^{2+}(0.54), \mathrm{UO}_{2}{ }^{2+}(0.095)$ and $\mathrm{Cu}^{2+}(1.27) \mathrm{mg}$ per $100 \mathrm{ml}$ analyte in: (A) $0.1 \mathrm{M} \mathrm{KCl}+0.001 \%$ gelatin, $\mathrm{pH} 4.5 \pm 0.1$; (B) $0.1 \mathrm{M} \mathrm{KSCN}+0.001 \%$ gelatin, $\mathrm{pH} 2.5 \pm$ 0.1 ; (C) $0.1 \mathrm{M}$ ammonium tartrate $+0.001 \%$ gelatin, $\mathrm{pH} 5.0 \pm 0.1$.

\section{Minimum tried detection limits}

The minimum tried detection limits of the DCP, DPP and DPASV techniques for measuring the individual and combined metal ions are given in Table 3. Except for $\mathrm{Cu}^{2+}$ and $\mathrm{UO}_{2}{ }^{2+}$, all of the metal ions in the sample could be determined in one run. For $\mathrm{Cu}^{2+}$ and $\mathrm{UO}_{2}^{2+}$, changing the supporting electrolyte was necessary. The detection limits were examined by synthetic samples. The data in Table 3 clearly reveal that the minimum tried detection limits in both cases, i.e., individual and combined, are $\mathrm{Zn}^{2+}$ (6.4), $\mathrm{Fe}^{3+}$ (5.6), $\mathrm{Mn}^{2+}$ (5.4), $\mathrm{Cu}^{2+}$ (6.3) and $\mathrm{UO}_{2}{ }^{2+}$ (2.4) $\mu \mathrm{g} \mathrm{l}^{-1}$ using DCP; it is 0.64 for $\mathrm{Zn}^{2+}, 0.56$ for $\mathrm{Fe}^{3+}$, 0.54 for $\mathrm{Mn}^{2+}$ and $0.063 \mu \mathrm{g} \mathrm{l}^{-1}$ for $\mathrm{Cu}^{2+}$ using DPP. However, for $\mathrm{UO}_{2}{ }^{2+}$, the tried detection limits using DPP are different for individual and combined forms, i.e., $2.4 \mu \mathrm{g} \mathrm{l}^{-1}$ and $4.8 \mu \mathrm{g} \mathrm{l}^{-1}$, respectively. In addition, the data also show that the DPASV method using a glassy carbon fiber electrode is highly sensitive 
for determining the reported metal ions down to the nanogram level, i.e., for $\mathrm{Zn}^{2+}$ (12.8), $\mathrm{Fe}^{3+}$ (2.8), $\mathrm{Mn}^{2+}$ (2.7) and $\mathrm{Cu}^{2+}$ (6.3) $\mathrm{ng}^{-1}$ in both the individual and combined forms. However the minimum tried detection limit for $\mathrm{UO}_{2}{ }^{2+}$ is found to be $0.24 \mathrm{ng}$

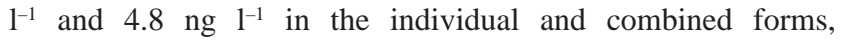
respectively using DPASV.

\section{Quantitative analysis of metal ions}

After ascertaining the presence of the said metals, a quantitative analysis of the sample was carried out by the standard addition method. The results are given in Table 4. The results indicate that the recovery was over $99 \%$ for most of

Table 2 Analysis of synthetic samples

\begin{tabular}{ccccc}
\hline \multicolumn{5}{c}{ Composition of synthetic samples } \\
\hline \multirow{2}{*}{$\mathrm{Zn}$} & 0.65 & 0.98 & 1.30 & 1.96 \\
& $(0.64)^{\mathrm{a}}$ & $(0.98)$ & $(1.31)$ & $(1.94)$ \\
$\mathrm{Fe}$ & 6.69 & 8.37 & 9.49 & 11.16 \\
& $(6.68)$ & $(8.36)$ & $(9.47)$ & $(11.15)$ \\
$\mathrm{Mn}$ & 0.54 & 0.84 & 1.10 & 1.64 \\
& $(0.55)$ & $(0.83)$ & $(1.09)$ & $(1.64)$ \\
$\mathrm{Cu}$ & 1.27 & 1.90 & 2.54 & 3.18 \\
& $(1.25)$ & $(1.90)$ & $(2.53)$ & $(3.16)$ \\
$\mathrm{U}$ & 0.095 & 0.142 & 0.190 & 0.238 \\
& $(0.092)$ & $(0.141)$ & $(0.187)$ & $(0.236)$ \\
\hline
\end{tabular}

Average of four determinations.

a. Amount found using DPP (mg per $100 \mathrm{ml}$ analyte). the metal ions with good precision of determination. The standard deviation and coefficient of variance were also calculated for spiked samples. The value of the standard deviation and coeffecient of variation never exceeded $0.05 \mathrm{mg}$ $\mathrm{g}^{-1}$ and $0.73 \%$, respectively, for all of the detected metal ions, except for $\mathrm{UO}_{2}{ }^{2+}$, for which the two values were 0.002 and $5.08 \%$, respectively, which clearly speaks about the accuracy and reliablity of the observed data.

The final analysis results for meta rhyolite rock samples are given in Table 5. These results were compared with those obtained using the AAS and XRF methods. The simplicity of the voltammetric methods for the qualitative and quantitative oligo analysis of the meta rhyolite rock sample with high

Table 3 Minimum tried detection limits

\begin{tabular}{ccccc}
\hline \multirow{2}{*}{ Metal ion } & $\begin{array}{c}\text { DCP/ } \\
\mu \mathrm{g} \mathrm{l}^{-1}\end{array}$ & $\begin{array}{c}\text { DPP/ } \\
\mu \mathrm{g} \mathrm{l}^{-1}\end{array}$ & $\begin{array}{c}\text { DPASV/ } \\
\mathrm{ng} \mathrm{l}^{-1}\end{array}$ \\
\hline $\mathrm{Zn}^{2+}$ & individual & 6.4 & 0.64 & 12.8 \\
& combined & 6.4 & 0.64 & 12.8 \\
$\mathrm{Fe}^{3+}$ & individual & 5.6 & 0.56 & 2.8 \\
& combined & 5.6 & 0.56 & 2.8 \\
$\mathrm{Mn}^{2+}$ & individual & 5.4 & 0.54 & 2.7 \\
& combined & 5.4 & 0.54 & 2.7 \\
$\mathrm{Cu}^{2+}$ & individual & 6.3 & 0.063 & 6.3 \\
& combined & 6.3 & 0.063 & 6.3 \\
$\mathrm{UO}_{2}{ }^{2+}$ & individual & 2.4 & 2.4 & 0.24 \\
& combined & 2.4 & 4.8 & 4.8 \\
\hline
\end{tabular}

Table 4 Results on meta rhyolite rock sample analysis for metal ions $\left(\mathrm{mg} \mathrm{g}^{-1}\right)$

\begin{tabular}{|c|c|c|c|c|c|c|c|c|c|}
\hline \multirow{2}{*}{$\begin{array}{l}\text { Metal } \\
\text { ion }\end{array}$} & \multirow{2}{*}{ Parameter } & \multicolumn{3}{|c|}{ DCP } & \multicolumn{3}{|c|}{ DPP } & \multicolumn{2}{|c|}{ DPASV } \\
\hline & & Added & & Found & Added & & Found & Added & Found \\
\hline \multirow{5}{*}{$\mathrm{Zn}^{2+}$} & Amount & - & & 22.22 & - & & 22.22 & - & 22.22 \\
\hline & & 20.10 & & 42.30 & 20.10 & & 42.30 & 20.10 & 42.24 \\
\hline & $\mathrm{R} \%$ & & $99.9 \%$ & & & $99.9 \%$ & & & \\
\hline & SD & & 0.03 & & & 0.04 & & & \\
\hline & $\mathrm{CV}$ & & $0.13 \%$ & & & $0.18 \%$ & & & \\
\hline \multirow[t]{5}{*}{$\mathrm{Fe}^{3+}$} & Amount & - & & 147.10 & - & & 147.10 & - & 147.10 \\
\hline & & 149.50 & & 296.50 & 149.50 & & 296.55 & 149.5 & 296.50 \\
\hline & $\mathrm{R} \%$ & & $99.9 \%$ & & & $99.9 \%$ & & & \\
\hline & SD & & 0.05 & & & 0.05 & & & \\
\hline & $\mathrm{CV}$ & & $0.03 \%$ & & & $0.03 \%$ & & & \\
\hline \multirow[t]{5}{*}{$\mathrm{Mn}^{2+}$} & Amount & - & & 5.50 & - & & 5.50 & - & 5.50 \\
\hline & & 5.00 & & 10.45 & 5.00 & & 10.40 & 5.00 & 10.42 \\
\hline & $\mathrm{R} \%$ & & $99.5 \%$ & & & $99.0 \%$ & & & \\
\hline & SD & & 0.04 & & & 0.04 & & & \\
\hline & $\mathrm{CV}$ & & $0.73 \%$ & & & $0.73 \%$ & & & \\
\hline \multirow[t]{5}{*}{$\mathrm{Cu}^{2+}$} & Amount & - & & 28.58 & - & & 28.58 & - & 28.58 \\
\hline & & 29.50 & & 57.90 & 29.50 & & 57.90 & 29.50 & 57.85 \\
\hline & $\mathrm{R} \%$ & & $99.7 \%$ & & & $99.7 \%$ & & & \\
\hline & SD & & 0.02 & & & 0.008 & & & \\
\hline & $\mathrm{CV}$ & & $0.07 \%$ & & & $0.03 \%$ & & & \\
\hline \multirow[t]{5}{*}{$\mathrm{UO}_{2}{ }^{2+}$} & Amount & - & & 0.059 & - & & 0.059 & - & 0.059 \\
\hline & & 0.057 & & 0.115 & 0.057 & & 0.114 & 0.057 & 0.115 \\
\hline & $\mathrm{R} \%$ & & $99.13 \%$ & & & $98.27 \%$ & & & \\
\hline & SD & & 0.0018 & & & 0.002 & & & \\
\hline & $\mathrm{CV}$ & & $3.05 \%$ & & & $3.38 \%$ & & & \\
\hline
\end{tabular}

Results are average of four determinations. $\mathrm{R} \%=$ Recovery $(\%), \mathrm{SD}=$ standard deviation, $\mathrm{CV}=$ coeffecient of variation. 
Table 5 Analytical results of meta rhyolite rock sample and the comparison with the results by AAS and XRF methods

\begin{tabular}{ccc}
\hline & \multicolumn{2}{c}{ Amount found in $\mathrm{mg} \mathrm{g}^{-1}$} \\
\cline { 2 - 3 } Metal ion & Voltammetry & AAS \\
\hline $\mathrm{Zn}^{2+}$ & 22.22 & 21.80 \\
$\mathrm{Fe}^{3+}$ & 147.10 & 146.95 \\
$\mathrm{Mn}^{2+}$ & 5.50 & 5.15 \\
$\mathrm{Cu}^{2+}$ & 28.58 & 28.60 \\
$\mathrm{UO}_{2}{ }^{2+}$ & 0.059 & $0.051^{\mathrm{a}}$ \\
\hline
\end{tabular}

a. Found by XRF method (only for $\mathrm{UO}_{2}{ }^{2+}$ ).

dependability, accuracy and precision of the determintion up to nanogram levels, suggests the utility of the said methods as being less time consuming and economical as well.

\section{Acknowledgements}

The authors are grateful to Professor S. P. Banerjee, Head, Department of Chemistry, Dr. H. S. Gour University, Sagar, for providing the necessary laboratory facilities.

\section{References}

1. A. Bermejo-Barrera, M. C. Yebra-Biurrum, and L. M. Fraga-Trillo, Anal. Chim. Acta, 1990, 239, 321.

2. M. Abdel' Fattakh, E. N. Ovsepyan, and A. G. Khachtryan, Zavod Lab., 1991, 57(3), 10.

3. L. R. Sawant, P. K. Kalsi, A. V. Kulkarni, and S. Vaidyanathan, J. Radioanal. Nucl. Chem., 1996, 207(1), 39

4. K. D. S. Mudher, J. Indian Chem. Soc., 1997, 74, 753.

5. J. Dostal, C. Dupuy, and J. D. Keppie, Can. J. Earth Sci., 1983, 20(2), 266
6. T. L. Spell and P. R. Kyle, J. Geophys. Res., Solid Earth Planets, 1989, 94(B8), 10379.

7. T. C. Moyer and L. D. Nealey, J. Geophys. Res., Solid Earth Planets, 1989, 94(B6), 7799.

8. C. J. Oates and R. C. Price, J. Geol. Soc. Aust., 1983, $30(1-2), 41$

9. M. Pinta and A. M. De Kersaabiec, Analusis, 1992, 20(1), M14.

10. G. E. M. Hall, C. J. Park, and J. C. Pelchat, J. Anal. At. Spectrom., 1987, 2(2), 189.

11. A. Voulgaropoulos, M. Paneli, E. Papaefstathiou, and S. Staroulias, Fresenius' J. Anal. Chem., 1991, 341(9), 568.

12. H. Bag, A. R. Turker, and M. Lale, Anal. Sci., 1999, 15 , 1251.

13. Q. L. Hou, T. C. Hughes, M. Haukka, and P. Hannaker, Talanta, 1985, 32(6), 495.

14. K. W. W. Sims and E. S. Gladney, Anal. Chim. Acta, 1991, 251(1-2), 297.

15. J. Chen, Y. Lin, X. Li, and Y. Ke, Fenxi Huaxue, 1990 , 18(10), 970 .

16. Y. Hamajima, M. Koba, K. Endo, and H. Nakahara, J. Radioanal. Nucl. Chem., 1985, 89(2), 315.

17. N. Verma and K. S. Pitre, Analyst, 1993, 118, 65.

18. C. Locatelli, Fresenius Envir. Bull., 1998, 7, 407.

19. M. Wojciechowski and J. Balcerzak, Anal. Chem. 1990, 62 , 1325.

20. T. Tanaka, T. Ishiyama, and K. Okamoto, Anal. Sci., 2000, $16,19$.

21. J. Shukla and K. S. Pitre, Analyst, 1996, 121, 79 .

22. M. A. Nolan and S. P. Kounaves, Anal. Chem., 1999, 71, 3567.

23. K. S. Rao, M. M. Palrecha, and R. G. Dhaneshwar, Bull. Electrochem., 1995, 11(7), 343.

24. J. Shukla and K. S. Pitre, Indian J. Chem., 1999, 38(A), 398.

25. C.-L. Zhou, Y. Lu, X.-L. Li, C.-N. Luo, Z.-W. Zhang, and J.-M. You, Talanta, 1998, 46, 1531. 